\title{
AN ANALYSIS OF THE USE OF AMERICAN SLANGS ON EMINEM'S SONG LYRICS
}

\author{
Luh Putu Karina Febriyanti Aryawan \\ Universitas Pendidikan Ganesha \\ e-mail: karina.febriyanti1004@gmail.com
}

\begin{abstract}
There were two types of speech style which could be divided into formal and informal type. The informal one was well-known by the name of slang. Slang was non-standard language used in the everyday life created by a certain community and usually used by the teenagers in modern era. Slang was not only found in the daily conversation, but also could be found in literary works like song. Song was a literary work which could reflect the reality and express someone's feelings. This study analyzes the slangs found in five lyrics of Eminem's song by using descriptive qualitative method. Besides, this study focused on the word formation of the slangs itself. There are 60 data which has been collected from the lyrics. From the analysis conducted, the types of word formation are found in the slangs used in the lyrics, such as blending, clipping, coinage, acronym and onomatopoeia. Mostly, the American slangs in the Eminem's song lyrics are created by the process of blending and clipping.
\end{abstract}

Keywords : speech style, slang, song lyrics, Eminem, word formation

\section{INTRODUCTION}

The style of speech can be divided into formal speech style and informal speech style. Informal speech style is also well-known as slang. According to Yanchun and Yanhong (2013), slang may be found in shape of single word and group of words or a sentence. Slang is kind of informal language that is used in informal situations. In another terminology, slang is part of a language that is out from the standard usage of language that may consists of new vocabularies and phrases with extended meanings attached to the original terms or words that belongs to a particular group (Yanchun \& Yanhong, 2013). From the terminologies stated above, it can be concluded that slang is an unofficial standard language that is used for communication in society life. In application, slang words are usually popular in young children, teenagers and college students. But actually, not all slangs belong to slang collections. It means that, people should recognize the slang words itself, so by the times it can be used in social conversation.

In general, the definition of slang is the non-standard language used in the everyday life. Slang words can be used in conversation and even literature such as movies, advertisement, songs, etc. Slang may be found in shape of single word and group of words or a sentence. According to Yanchun and Yanhong (2013), slang is part of a language that is out from the standard usage of daily life language that may consists of new vocabularies and phrases with extended meanings attached to the original terms or words that belongs to a particular group.

"Slang words and expressions are characterized by a high degree of informality, familiarity, vocabulary richness. They are realized by a specific group of people whose members are connected with some particular link, such as territory (Californian), age (teenagers), subculture (students), and mainly occur in the spoken form of the language." (Burdova, 2009) cited in Astriyani (2000).

Another terminology said that slang is a kind of code or secret language which is used by some people or community group in society (Astriyani, 2000). It is caused by the development of the language variations in the society, especially by advertisement, songs, etc.

Slangs can also be found in literary works that are connected with the social life, the 
followings are: movies, poetries, songs, novels, and short stories (Oktavia, 2017). Besides, those kind of literary works can affect the development of language in this new era that will upgrade the slang languages in decade or months, even days. One of literary works that has the biggest impact in developing the slang words is song, especially Rap or Hip Hop song that contains a lot of aesthetical and meaningful lyrics about anger and sarcasm. Rap song that uses American Slang is naturally made and used by males and black people in United States (Yanchun \& Yanhong, 2013). One of the famous figure that is well-known with his slangs is Eminem, the one who becomes a successful rapper in United States. Eminem can stand out with his slang words among the American in United States, because the people in United States tend to use Eminem's "dope" slangs and other slangs created by the popular hip hop singers in their daily life conversations (Yanchun \& Yanhong, 2013).

There are some reseachers who already do the research about slang language in the previous study. The first study is about "An Analysis of Slang Language Related to Sex in Eminem's Rap Songs' Lyrics" which is conducted by Astriyani (2000). She classifies the data that belongs to sexual perversion, gender identity sexuality and sexual attraction. The second study is conducted by Mukthar, A. (2010) entitled "Analysis on the Use of Slang on Eminem's Lyrics". This study is analyzing the characteristics of slangs used in Eminem's song lyrics such as fresh, creativity, flippant, and onomatopoeic.

In this present study which is based on the matters above, the writer will conduct a research about the analysis of the Eminem's songs entitled, "An Analysis of the Use of American Slangs on Eminem's Song Lyrics" by concerning two problems, such as the types of the slangs found in the lyrics by using word formation and analysis the standard word or meaning of the slangs used in Eminem's song lyrics.

\section{THEORICAL FRAMEWORK Previous Study}

The research about analyzing the song lyrics has been conducted by other researchers. The study entitled "An Analysis of Slang Language Related to Sex in Eminem's Rap Songs' Lyrics" (Astriyani, 2000) classifies the slang words into three parts based on the sexual kind of slangs as follows: sexual perversion, gender identity sexuality and sexual attraction. She puts the slangs which are found in the lyrics to its belonging, for example fag belongs to sexual perversion, bitch belongs to gender identity sexuality and bush belongs to sexual attraction.

The study which is conducted by Abadi (2010) entitled "Analysis on the Use of Slang on Eminem's Lyrics" explains that the characteristics of slang language can be divided into four parts as the follows: fresh, creativity, flippant, and onomatopoeic. He found out that the slang words used in the Eminem's song lyrics can be characterized into those kinds of characteristic. For example, $s h^{*} t$ belongs to flippant, blackballed belongs to creativity, witcha belongs to fresh, and tryin' belongs to onomatopoeic. There is a difference between this previous study and the present study, in which the object of the previous study is the characteristic of slangs and the present study is trying to look at the types of slangs which uses the word formation.

\section{Word Formation}

As time goes on, the language will also develop. O'Grady (1996) cited in (Astriyani, 2000) stated that one kind of the so-called "language development" is using word formation to create a new word. Word belongs to a part of language which has an important role to form language. People should know where the language comes from, how the language formed and the meaning is built. So it means that the process of forming a word influences the meaning of a word. This process is being called word formation process.

\section{Types of Word Formation}

In the field of English linguistics, there are some types of word formation in the process of forming a new word. But in this 
section, I attempted to focus on five types of word formation cited from (Wahyuni \& Rosa, 2013) and (Wulandari \& Ardi, 2012), the following are:

\section{a. Acronym}

Acronym is a process of forming a new word in which the word will be formed from the initial letters of a set of words. It usually can be seen in the organizations names and some kinds of terminologies. The examples are NATO which stands for North Atlantic Treaty Organization, AIDS stands for Acquired Immune Deficiency Syndrome, and U.S stands for United State. In another hand, the acronym will be found in daily conversations such as YOLO which means You Only Live Once, SMH means Shake My Head, ASAP stands for As Soon As Possible, and ILY stands I Love You. So, acronym will be used to form a slang word in which only the first initials are used.

\section{b. Back Formation}

Back formation is a process of deriving a word in which the actual affixes will be deleted or removed to derive a new lexeme, but in backwards way. For example as follows:

- Peddle < Peddler

- Baby-sit < Baby Sitter

- Daydream < Daydreamer

- Greed < Greedy

- Housekeep < Housekeeper

- Televise < Television

\section{c. Blending}

Blending is a process of forming a lexeme in which there is a combination between two or more words. Blending will take the beginning of word then combine it with the end of the other word. It also can be combined by taking the beginning of both words. The examples are the followings:

- Smog $=$ smoke + fog

- Motel $=$ motor + hotel

- Brunch $=$ Breakfast + Lunch

- Wanna $=$ Want + to

- Kinda $=$ Kind + of

- Ain't = Am/are/ is + not

- Pickpocket $=$ Pick + Pocket

\section{d. Clipping}

Clipping is a process of deriving a new lexeme by reducing or deleting the parts of word (one or more syllables) to make the word become shorter but the meaning is still the same (O'Grady and Guzman, 1996: 157) in Wahyuni, S. and Rosa, N.R. (2013).

- Foreclipping is a process of making a new word by cutting the first part of the original word. For examples, burger for hamburger, phone for telephone, Uni for University, exam for examination, etc.

- Fore-back clipping is a process of making a new word by deleting the first part and the end part of the original word. But this kind of clipping is rarely used. For examples, flue for influenza, jams for pajamas or pyjamas.

e. Coinage

Coinage is a word formation process in which a new lexeme or word will be created. In the point, it adapts the words that already exist. It is usually defined as the new words or terms invention. Coinage mostly indicates the name of products and company. The examples are as the followings: aspirin, nylon, Kleenex, Honda, Vaseline, Xerox, Google, heroin.

\section{f. Derivation}

Derivation is a process of creating a new lexeme or word by adding the affixes in which the word will have a different meaning and be in different word class base. To derive the new words, prefixes (the letters attached in the beginning of word) or suffixes (the letters attached in the end of a word) is usually needed. According to O'Grady (1996) in the research of Wahyuni, S. and Rosa, R.N (2013), in linguistics this derivation process can be divided into three kinds, such as prefix, infix, and suffix. But, infix is rarely seen than prefixes and suffixes. The following is the example of prefixes and suffixes in English:

- Prefixes: re-, dis-, un-, anti-, in-, pre-, post-, ante-, and sub-.

- Suffixes: -ation, -full, -able, -act. -ist, -ness, -ity, -ty, -ship, etc.

- Infixes: hallebloodylujah, fan-flaming-tastic, me-bloody-self, etc.

g. Onomatopeia

Onomatopeia is a process of word formation in which it will represent an aspect of the thing so later people can identify that thing's name. For example, buzz (represent bee), meow (represents cat), and cock-a-doodle-doo (represents male chicken). Therefore, 
onomatopoeic words may vary from language to language. It is because the onomatopoeic words in other languages do not have the same

\section{METHOD}

\section{Research Design}

According to Mc Millar and Schumacher (1993:31) in "Analysis on the Use of Slang on Eminem's Lyrics" (Mukhtar, 2010), research design is an investigation plan used in order to collect the evidences to answer the research problem. To complete this research, I attempt to use the descriptive qualitative research design because this research only describes the kinds of word formation of slang language used in Eminem's song lyrics along with its meaning. According to Gay (1987:11) in Mukhtar (2010), descriptive research is a research design which will answer the question related to the object of the study based on the data that has been collected. Besides, descriptive study only report things and measure what already exist. It is including when, from whom, and how the data is obtained. The objective of this research design is to give the most valid answer for each problem stated.

\section{Scoop and Limitation}

The data which is analyzed in this reseach is focused on the slangs in Eminem's song lyrics. For the main source of the data is taken from Eminem's song lyrics in their album "Slim Shady LP" released in 1999 (Cum on Everybody) as the data source. Then the second album entitled "The Marshall Mathers LP (2000)" with the songs "Stan" and "The Way I am." The third album entitled "The Eminem Show" released in 2002 with the songs titled "Cleaning out My Closet" and "White America." Then, "Love Me" from "Eminem Presents The Re-Up" album which is released on 2006. The last is the song "Rap God" which is taken from the album The Marshall Mathers LP 2 released in 2013. So the total of the song which will be analysed is five songs. The slangs which are found will be analyzed based on the theories related to the topic. words as in English onomatopoeic. For example, nya (represent cat in Japanese) and niyaw (represents cat in Tagalog).

\section{Data}

The kind of data in this study is in the forms of written data, such as song lyrics which are focused on the slangs and the vocabularies found in the lyrics. So the main data will be gathered from five of Eminem's song lyrics. The songs are Love Me (2006), Rap God (2013), Cleaning out My Closet (2002), Stan (2000), Cum on Everybody (1999).

\section{Procedure of Collecting Data}

In order to complete this research, there are four steps in collecting the data. I attempted to: (1) read and understand the meaning of the lyrics, (2) find out the slang words in used in the song lyrics, (3) highlight the slang words which are found in the lyrics, and (4) classify the slang words into each types of slang words by using word formation.

\section{Data Analysis}

In order to analyze the collected data, I will use the descriptive qualitative research, in which this technique will answer the question related to the object of the study. Besides, descriptive study only report things and measure what already exist. The data analysis can be done by doing four steps of processing the data, such as: (1) organizing the slang words which are already found in the lyrics, (2) finding the meaning of each slang words, (3) classifying the type of slang words by using word formation, and (4) making conclusion of the analysis.

\section{FINDING AND DISCUSSION}

Slangs do not only exist in conversations or dialogue, but slangs are also there gaining its existence in literary works connected to the daily life. One of that literary works is song. A song usually reflects the reality happened in daily life and a way to express people's feelings. The concrete example of this case is the use of 
slangs in the lyrics of the song. This study analyzes five lyrics of Eminem's songs. From the data collected, the song lyrics contain many slangs with its own word formation. The type of word formations which are found in the lyrics are blending, clipping, acronym, coinage and onomatopoeia. There are 60 data which are already collected and it will be divided by its own word formation type by using tables.

Table 1. Love Me Lyrics

\begin{tabular}{|c|c|c|c|}
\hline Slangs & Sentence & Standard Word & $\begin{array}{l}\text { Word } \\
\text { Formation }\end{array}$ \\
\hline $\operatorname{Ain}^{\prime} t$ & $\begin{array}{l}\text { And I ain't } \\
\text { here to meet } \\
\text { a soul in this } \\
\text { business }\end{array}$ & $\begin{array}{l}\text { Is/am/are + not = } \\
\text { ain't. The best } \\
\text { word for this } \\
\text { sentence is I am } \\
\text { not }\end{array}$ & Blending \\
\hline Y'all & $\begin{array}{l}\text { I can't let y'all } \\
\text { derail me man }\end{array}$ & $Y o u+a l l=Y^{\prime}$ all & Blending \\
\hline Gotta & $\begin{array}{l}\text { I got young } \\
\text { Kobe, homie, } \\
\text { you gotta let } \\
\text { go of Obie }\end{array}$ & Got + to $=$ Gotta & Blending \\
\hline Tourin' & $\begin{array}{l}\text { Soon as a } \\
\text { nigga touch } \\
\text { down back }\end{array}$ & Touring & Clipping \\
\hline Nigga & $\begin{array}{l}\text { Soon as a } \\
\text { nigga touch } \\
\text { down back } \\
\text { from tourin' }\end{array}$ & $\begin{array}{l}\text { Nigger, meaning } \\
\text { an informal } \\
\text { offensive words } \\
\text { representing } \\
\text { urban African- } \\
\text { American speech }\end{array}$ & Coinage \\
\hline Whateva & $\begin{array}{l}\text { It's whateva, } \\
\text { put that on } \\
\text { the chedda } \\
\text { man }\end{array}$ & Whatever & Coinage \\
\hline Chedda & $\begin{array}{l}\text { It's whateva, } \\
\text { put that on } \\
\text { the chedda } \\
\text { man }\end{array}$ & $\begin{array}{l}\text { Cheddar, meaning } \\
\text { money, rich }\end{array}$ & Clipping \\
\hline Motherfuckin' & $\begin{array}{l}\text { Now I'm here } \\
\text { so shut your } \\
\text { motherfuckin } \\
\text { mouth }\end{array}$ & $\begin{array}{l}\text { Motherfucking. In } \\
\text { the sentence } \\
\text { term, } \\
\text { motherfucking } \\
\text { mouth means } \\
\text { close vour bad }\end{array}$ & Clipping \\
\hline
\end{tabular}




\begin{tabular}{|c|c|c|c|}
\hline Wanna & $\begin{array}{l}\text { I just wanna } \\
\text { love you for } \\
\text { the rest of my } \\
\text { life }\end{array}$ & Want to & Blending \\
\hline Sorta & $\begin{array}{l}\text { That you } \\
\text { notice that it's } \\
\text { sorta unique }\end{array}$ & $\begin{array}{l}\text { Sort of, combining } \\
\text { sort and of }\end{array}$ & Blending \\
\hline Tryin & $\begin{array}{l}\text { You can't sit } \\
\text { still, it's like } \\
\text { tryin to smoke } \\
\text { crack }\end{array}$ & Trying & Clipping \\
\hline Cockadoodle & $\begin{array}{l}\text { My noodle is } \\
\text { cockadoodle, } \\
\text { my clocks } \\
\text { cuckoo }\end{array}$ & $\begin{array}{l}\text { Cockadoodle } \\
\text { means a male } \\
\text { chicken voice }\end{array}$ & $\begin{array}{l}\text { Onomatope } \\
\text { ia }\end{array}$ \\
\hline Rollin & $\begin{array}{l}\text { I'm rollin with } \\
\text { a swollen } \\
\text { bowling ball in } \\
\text { my bag }\end{array}$ & Rolling & Clipping \\
\hline Fag & $\begin{array}{l}\text { You need a } \\
\text { fag to come } \\
\text { and tear a } \\
\text { new hole in } \\
\text { my ass }\end{array}$ & $\begin{array}{l}\text { Faggot, means an } \\
\text { extremely } \\
\text { offensive word } \\
\text { for a homosexual } \\
\text { (gay) man. }\end{array}$ & Clipping \\
\hline
\end{tabular}

Table 2. Rap God Lyrics

\begin{tabular}{llll}
\hline & & & Word \\
Slangs & Sentence & Correct Word & Formation \\
\hline Pen'll & $\begin{array}{l}\text { My pen'll go } \\
\text { off when I } \\
\text { half-cock it }\end{array}$ & Pen + will = Pen'll & Blending \\
& &
\end{tabular}

\begin{tabular}{|c|c|c|c|}
\hline Motherfuckin & $\begin{array}{l}\text { I'll still be able } \\
\text { to break a } \\
\text { motherfuckin' } \\
\text { table }\end{array}$ & $\begin{array}{l}\text { Motherfucking. } \\
\text { In the sentence } \\
\text { term, } \\
\text { motherfucking } \\
\text { table means a } \\
\text { bad or annoying } \\
\text { table. }\end{array}$ & Clipping \\
\hline$N^{\prime}$ & $\begin{array}{l}\text { Into the } \\
\text { motherfuckin' } \\
\text { Rock n' Roll } \\
\text { Hall of Fame } \\
\text { even though I } \\
\text { walk in the } \\
\text { church }\end{array}$ & And & Coinage \\
\hline
\end{tabular}




\begin{tabular}{|c|c|c|c|}
\hline Fags & $\begin{array}{l}\text { You fags think } \\
\text { it's all a game }\end{array}$ & $\begin{array}{l}\text { Faggot, means an } \\
\text { extremely } \\
\text { offensive word for } \\
\text { a homosexual }\end{array}$ & Clipping \\
\hline 'Til & $\begin{array}{l}\text { 'Til I walk a } \\
\text { flock of } \\
\text { flames }\end{array}$ & Until & Clipping \\
\hline$D^{\prime}$ you & $\begin{array}{l}\text { Hey, looking } \\
\text { boy, what } \\
\text { d'you say, } \\
\text { looking boy? }\end{array}$ & $\begin{array}{l}\text { Did + you or Do + } \\
\text { you }=d^{\prime} \text { you }\end{array}$ & Blending \\
\hline Outta & $\begin{array}{l}\text { Get outta my } \\
\text { face, looking } \\
\text { boy }\end{array}$ & Out + of $=$ outta & Blending \\
\hline Totin' & $\begin{array}{l}\text { Immediately } \\
\text { with these } \\
\text { bombs I'm } \\
\text { totin' }\end{array}$ & $\begin{array}{l}\text { Toting, meaning } \\
\text { that the practice } \\
\text { of taking home } \\
\text { food from an } \\
\text { employer by a } \\
\text { person engaged } \\
\text { in domestic } \\
\text { service, or the } \\
\text { food so taken }\end{array}$ & Clipping \\
\hline Wanna & $\begin{array}{l}\text { At least once } \\
\text { in a while so I } \\
\text { wanna make } \\
\text { sure }\end{array}$ & Want to & Blending \\
\hline Gotta & $\begin{array}{l}\text { But I gotta } \\
\text { keep a few } \\
\text { punchlines }\end{array}$ & Got + to $=$ Gotta & Blending \\
\hline 'em & $\begin{array}{l}\text { Put 'em all in } \\
\text { a line }\end{array}$ & Them & Clipping \\
\hline Morphin' & $\begin{array}{l}\text { Morphin' into } \\
\text { an immortal } \\
\text { coming } \\
\text { through the } \\
\text { portal }\end{array}$ & $\begin{array}{l}\text { Morphing, } \\
\text { meaning that } \\
\text { addicted into or } \\
\text { addicted to } \\
\text { something }\end{array}$ & Clipping \\
\hline Singin' & $\begin{array}{l}\text { At } \\
\text { Mayweather's } \\
\text { pad singin' to } \\
\text { a man }\end{array}$ & Singing & Clipping \\
\hline Imma & $\begin{array}{l}\text { "Hey, Fab, } \\
\text { I'mma kill } \\
\text { you" }\end{array}$ & $\begin{array}{l}\text { I } a m+\text { going + to } \\
=I m m a\end{array}$ & Blending \\
\hline
\end{tabular}




$\begin{array}{ll}\text { Hurtin' } & \text { It's curtains, Hurting Clipping } \\ & \text { I'm } \\ & \text { inadvertently } \\ & \text { hurtin' you }\end{array}$

Table 3. Cleaning Out My Closet

\begin{tabular}{llll}
\hline & & & Word \\
Slangs & Sentence & Correct Word & Formation \\
\hline 'em & Tempers & Pen + will = Pen'll & Clipping \\
& flaring from & & \\
& parents just & & \\
& blow 'em off & & \\
& and keep & & \\
& going & &
\end{tabular}

\begin{tabular}{|c|c|c|c|}
\hline Ya & $\begin{array}{l}\text { Look at me } \\
\text { now; I bet ya } \\
\text { probably sick } \\
\text { of me now } \\
\text { ain't you } \\
\text { mama? }\end{array}$ & $\begin{array}{l}\text { Motherfucking. } \\
\text { In the sentence } \\
\text { term, } \\
\text { motherfucking } \\
\text { table means a } \\
\text { bad or annoying } \\
\text { table. }\end{array}$ & Coinage \\
\hline $\operatorname{Ain}^{\prime} t$ & $\begin{array}{l}\text { Look at me } \\
\text { now; I bet ya } \\
\text { probably sick } \\
\text { of me now } \\
\text { ain't you } \\
\text { mama? }\end{array}$ & And & Blending \\
\hline Imma & $\begin{array}{l}\text { Imma make } \\
\text { you look so } \\
\text { ridiculous } \\
\text { now }\end{array}$ & $\begin{array}{l}\text { Faggot, means an } \\
\text { extremely } \\
\text { offensive word for } \\
\text { a homosexual }\end{array}$ & Blending \\
\hline$l^{\prime} d a$ & $\begin{array}{l}\text { 'Cause I'da } \\
\text { killed him; } \\
\text { shit I would've } \\
\text { shot Kim and } \\
\text { him both }\end{array}$ & $\begin{array}{l}I+\text { would + have }= \\
I^{\prime} d a\end{array}$ & Blending \\
\hline 'Til & $\begin{array}{l}\text { Hey, looking } \\
\text { boy, what } \\
\text { d'you say, } \\
\text { looking boy? }\end{array}$ & Until & Clipping \\
\hline Gonna & $\begin{array}{l}\text { Get outta my } \\
\text { face, looking } \\
\text { boy }\end{array}$ & $\begin{array}{l}\text { Going }+ \text { to }= \\
\text { gonna }\end{array}$ & Blending \\
\hline
\end{tabular}


Table 4. Stan

\begin{tabular}{llll}
\hline Slangs & Sentence & Correct Word & $\begin{array}{l}\text { Word } \\
\text { Formation }\end{array}$ \\
\hline$I t^{\prime} \mid l$ & And even if I & $I t+$ will $=i t^{\prime} l l$ & Blending \\
& $\begin{array}{l}\text { could it'll all } \\
\text { be gray, but }\end{array}$ & $I t+$ shall = it'll & \\
& your picture & & \\
& on my wall & &
\end{tabular}

\begin{tabular}{|c|c|c|c|}
\hline Ain't & $\begin{array}{l}\text { Dear Slim, I } \\
\text { wrote you but } \\
\text { you still ain't } \\
\text { calling }\end{array}$ & $\begin{array}{l}\text { Is/am/are + not. } \\
\text { In this case, are } \\
\text { not/aren't is } \\
\text { appropriate to } \\
\text { use }\end{array}$ & Blending \\
\hline 'em & $\begin{array}{l}\text { I sent two } \\
\text { letters back in } \\
\text { autumn, you } \\
\text { must not-a } \\
\text { got 'em }\end{array}$ & Them & Clipping \\
\hline Imma & $\begin{array}{l}\text { I'mma name } \\
\text { her Bonnie }\end{array}$ & $\begin{array}{l}I+a m+\text { going }+ \\
\text { to }=I^{\prime} m m a\end{array}$ & Blending \\
\hline Gotta & $\begin{array}{l}\text { You gotta call } \\
\text { me man, I'll } \\
\text { be the biggest } \\
\text { fan you'll ever } \\
\text { lose }\end{array}$ & Got + to $=$ gotta & Blending \\
\hline This'll & $\begin{array}{l}\text { This'll be the } \\
\text { last package I } \\
\text { ever send } \\
\text { your ass }\end{array}$ & $\begin{array}{l}\text { This + will = this'll } \\
\text { This + shall = } \\
\text { this'll }\end{array}$ & Blending \\
\hline Coulda & $\begin{array}{l}\text { That's kinda } \\
\text { how this is, } \\
\text { you coulda } \\
\text { rescued me } \\
\text { from } \\
\text { drowning }\end{array}$ & $\begin{array}{l}\text { Could }+ \text { have }= \\
\text { coulda }\end{array}$ & Blending \\
\hline Musta & $\begin{array}{l}\text { I'm sorry I } \\
\text { didn't see you } \\
\text { at the show, I } \\
\text { musta missed } \\
\text { you }\end{array}$ & $\begin{array}{l}\text { Must + have }= \\
\text { musta }\end{array}$ & Blending \\
\hline
\end{tabular}




$\begin{array}{ll}C^{\prime} m o n & \begin{array}{l}\text { C'mon! How } \\ \text { fucked up is } \\ \text { you? }\end{array}\end{array}$

Table 5. Cum on Everybody

\begin{tabular}{|c|c|c|c|}
\hline Slangs & Sentence & Correct Word & $\begin{array}{l}\text { Word } \\
\text { Formation }\end{array}$ \\
\hline Whattup & $\begin{array}{l}\text { Testing one, } \\
\text { two, um... } \\
\text { twelve } \\
\text { (whattup } \\
\text { whattup } \\
\text { whattup) }\end{array}$ & $\begin{array}{l}\text { Shorten form } \\
\text { from What's up }\end{array}$ & Blending \\
\hline Grabbin & $\begin{array}{l}\text { Women all } \\
\text { grabbin at my } \\
\text { shishkabob }\end{array}$ & Grabbing & Clipping \\
\hline AIDS & $\begin{array}{l}\text { Shit I got full } \\
\text { blown AIDS } \\
\text { and a sore } \\
\text { throat }\end{array}$ & $\begin{array}{l}\text { Acquired Immune } \\
\text { Deficiency } \\
\text { Syndrome }\end{array}$ & Acronym \\
\hline Signin & $\begin{array}{l}\text { I'm in the } \\
\text { fourth row, } \\
\text { signin } \\
\text { autographs at } \\
\text { your show }\end{array}$ & Signing & Clipping \\
\hline Freestylin & $\begin{array}{l}\text { I'm freestylin } \\
\text { every verse } \\
\text { that I spit }\end{array}$ & $\begin{array}{l}\text { Freestyling, } \\
\text { meaning a genre } \\
\text { of rap music }\end{array}$ & Clipping \\
\hline Doc & $\begin{array}{l}\text { I told the doc I } \\
\text { need a change } \\
\text { in sickness }\end{array}$ & Doctor & Clipping \\
\hline Wanna & $\begin{array}{l}\text { You wanna } \\
\text { get high, here } \\
\text { bitch just sniff } \\
\text { this }\end{array}$ & $\begin{array}{l}\text { Want }+ \text { to }= \\
\text { Wanna }\end{array}$ & Blending \\
\hline
\end{tabular}




\begin{tabular}{|c|c|c|c|}
\hline Cause & $\begin{array}{l}\text { Cause I don't } \\
\text { give a fuck, } \\
\text { like my } \\
\text { middle finger } \\
\text { was stuck }\end{array}$ & Because & Clipping \\
\hline Wavin' & $\begin{array}{l}\text { And I was } \\
\text { wavin it at } \\
\text { everybody } \\
\text { screamin, "I } \\
\text { suck" (I } \\
\text { SUCK!!!!) }\end{array}$ & Waving & Clipping \\
\hline Screamin' & $\begin{array}{l}\text { And I was } \\
\text { wavin it at } \\
\text { everybody } \\
\text { screamin, "I } \\
\text { suck" (I } \\
\text { SUCK!!!) }\end{array}$ & Screaming & Clipping \\
\hline Y'all & $\begin{array}{l}\text { All y'all get } \\
\text { the hell out } \\
\text { now }\end{array}$ & You + all = Y'all & Blending \\
\hline Givin' & $\begin{array}{l}\text { Fuck rap, I'm } \\
\text { givin it up } \\
\text { y'all, I'm sorry }\end{array}$ & Giving & Clipping \\
\hline Execedrin & $\begin{array}{l}\text { One Excedrin } \\
\text { tablet short of } \\
\text { a full } \\
\text { medicine } \\
\text { cabinet }\end{array}$ & $\begin{array}{l}\text { Excedrin means a } \\
\text { headache } \\
\text { medicine }\end{array}$ & Coinage \\
\hline 'em & $\begin{array}{l}\text { I told em, } \\
\text { "Meet me at } \\
\text { Kid Rock's } \\
\text { next concert" }\end{array}$ & Them & Clipping \\
\hline Tylenol & $\begin{array}{l}\text { Crushed up } \\
\text { the Tylenol } \\
\text { and ate it with } \\
\text { a dipstick }\end{array}$ & $\begin{array}{l}\text { Tylenol means } \\
\text { paracetamol (a } \\
\text { medicine which is } \\
\text { used to decrease } \\
\text { the fever, anti- } \\
\text { body) }\end{array}$ & Coinage \\
\hline
\end{tabular}

In this part of article, the author will represent the findings which have been analyzed by using word formation type. Based on the result of the findings, the author can conclude that there are 60 data of slangs used and found in phrases of the five Eminem's song lyrics. From the analysis conducted, the author is successfully collecting the types of slangs by using word formation. Those types are blending, coinage, clipping, acronym and onomatopoeia. The slangs found are mostly created by blending and clipping formation process. The slangs do not change the meaning, but it only reforms the word itself. 


\section{CONCLUSION}

In conclusion, from the analysis of slang words in the lyrics of Eminem's songs, there are some slangs which can be found and exist in the songs which have been analyzed. Mostly, slangs appear in hip hop or rap songs such as Eminem's.

Based on the analysis above, there are five types of word formation which are used to analyze the slangs. The first type is clipping, such as screamin', wavin', givin', grabbin', etc. The second type is acronym. In this type, there is one slang, AIDS. The third type of slangs is blending such as, wanna, l'da, ain't, gonna, imma, gotta, y'all, etc. The fourth type of slang is back coinage such as ya, Tylenol, Excedrin, n', etc. The last type is Onomatopeia, such as cockadoodle. Besides, from the analysis above, the slang words are mostly created by blending and clipping formation process. The slang words only reform the word, and the meaning of the slangs do not change the original meaning of the song.

\section{REFERENCES}

Astriyani. (2000). AN ANALYSIS OF SLANG LANGUAGE RELATED TO SEX IN EMINEM'S RAP SONGS' LYRICS. English Department. Faculty of Letters. Gunadarma University.

Bass, J., Bass, M., \& Mathers, M. (Composers). (1999). Cum on Everybody. [Eminem, Performer]

Jackson, C., King, S., Mathers, M., Resto, L., \& Trice, O. (Composers). (1999). Love Me. [Eminem, Performer]
Mathers, M., Zayas, B., Delgiorno, M., Hacker, S., Davis, D., Walters, R., et al. (Composers). (2013). Rap God. [Eminem, Performer]

Mathers, M., \& Bass, J. (Composers). (2002). Cleaning Out My Closet. [Eminem, Performer]

Mathers, M., Dido, \& Harmon, P. (Composers). (2000). Stan. [Eminem, \& Dido, Performers]

McMillan, L., \& Wagner, S. (n.d.). Dictionary.com. Retrieved December 11, 2017, from 2017 Dictionary.com, LLC.: www.dictionary.com

Mukhtar, A. (2010). Analysis on the Use of Slang on Eminem's Lyrics. Thesis Master of art, Malang: University of Maulana Malik Ibrahim.

Oktavia, V. (2017). AN ANALYSIS OF SLANG WORDS IN THE LYRICS OF FAR EAST MOVEMENT SONG AS THE FORM OF LANGUAGE DEVELOPMENT AND IT'S USED IN THE DAILY LIFE. The 1st Education and Language International Conference Proceedings Center for International Language Development of Unissula, (pp. 899 - 904). College of Language Sultan Agung Islamic University.

Wahyuni, S., \& Rosa, R. (2013). TYPES OF WORD FORMATION OF SLANG WORDS FOUND IN TV ADVERTISEMENT. English Language and Literature E-Journal, ISSN 2302-3546.

Wulandari, P., \& Ardi, H. (2012). THE TYPES OF SLANG WORDS IN THE LYRICS OF "JIGSAW" ALBUM BY LADY SOVEREIGN. Padang: FBS State University of Padang.

Yanchun, Z., \& Yanhong, F. (2013). A Sociolinguistic Study of American Slang. Theory and Practice in Language Studies, Vol.3, No.12, 2209-2213, DOI:10.4304/tpls.3.12.2209-2213. 